\title{
FAKTOR-FAKTOR YANG BERHUBUNGAN DENGAN TERJADINYA HIPERTENSI PADA LANSIA DI PUSKESMAS III DENPASAR UTARA TAHUN 2012
}

\author{
Wulandari, Ratna ${ }^{1}$; Putra, Kadek Agus Dwija ${ }^{2}$; Sandi, I Wayan ${ }^{3}$ \\ 1,2 Akademi Keperawatan Kesdam IX/Udayana \\ ${ }^{3}$ Rumah Sakit Angkatan Darat Tk. II Udayana \\ *Korespondensi : agusdwija@ymail.com
}

\begin{abstract}
Background: The prevalence of isolated systolic hypertension (HST) is expected to occur approximately $25 \%$ in the age group of $60-90$ years, and found as much as $59.1 \%$ in males and $61.9 \%$ in females. This research aims to determine the factors related to the incidence of hypertension in the elderly. Methods: This study uses a descriptive analytical design with the Cross Sectional approach. The research samples used are seniors aged $\geq 60$ years and older with Consecutive Sampling technique in the working area of Puskesmas III North Denpasar. Data retrieval takes place from April to May 2012 by filling out questionnaires, measuring weight, height and blood pressure. The Data obtained is analyzed univariate and bivariate using Chi-Square test. Results: Based on the analysis gained that the factors associated with the occurrence of hypertension in the elderly are The age factor (OR: 10,833; 95\% CI: 1,961-59,834), Gender factor (OR: 7,467; 95\% CI: 1,400-39,837), Genetic factor (OR: 10,083; 95\% CI: 1,658-61,330), Activity factors (OR: 0,095; 95\% CI: 0,0170,529), and the habit of drinking coffee (OR: 15,556; 95\% CI: 2,586-93,571). Conclusion: Age, gender, genetic, activity and coffee habits are factors related to hypertension in the elderly. Expected parties are more promoting health programs in the elderly, especially on hypertensive diseases
\end{abstract}

Keywords: hypertension; elderly; activities; drinking coffee

ABSTRAK

Latar belakang: Prevalensi Hipertensi Sistolik Terisolasi (HST) diperkirakan terjadi sekitar 25\% pada kelompok umur 60-90 tahun, dan ditemukan sebanyak 59,1\% pada laki-laki dan $61,9 \%$ pada perempuan. Penelitian ini bertujuan untuk mengetahui faktor-faktor yang berhubungan dengan kejadian hipertensi pada lansia. Metode: Penelitian ini menggunakan desain deskriptif analitik dengan pendekatan Cross Sectional. Sampel penelitian yang digunakan adalah lansia yang berumur $\geq 60$ tahun keatas dengan`menggunakan teknik Consecutive Sampling di wilayah kerja 
puskesmas III Denpasar Utara. Pengambilan data dilakukan pada bulan April hingga Mei 2012 dengan cara pengisian kuesioner, pengukuran berat badan, tinggi badan dan tekanan darah. Data yang diperoleh dianalisis secara univariat dan bivariat menggunakan uji Chi-Square. Hasil: berdasarkan analisis diperoleh bahwa faktorfaktor yang berhubungan dengan terjadinya hipertensi pada lansia adalah faktor umur (OR:10,833; 95\%CI: 1,961-59,834), faktor jenis kelamin (OR:7,467; 95\%CI:1,40039,837), faktor genetik (OR:10,083; 95\%CI:1,658-61,330), faktor aktivitas (OR:0,095; 95\%CI:0,017-0,529), dan kebiasaan minum kopi (OR:15,556; 95\%CI:2,586-93,571). Simpulan: Faktor umur, jenis kelamin, genetik, aktifitas dan kebiasaan minum kopi merupakan faktor-faktor yang berhubungan dengan penyakit hipertensi pada lansia. Diharapkan pihak terkait lebih mempromosikan programprogram kesehatan pada lansia, khususnya mengenai penyakit hipertensi.

Kata kunci: Hipertensi; Lansia; aktifitas; minum kopi

\section{PENDAHULUAN}

Di Dunia jumlah lansia diperkirakan sekitar 500 juta dengan usia rata-rata 60 tahun dan diperkirakan pada tahun 2025 akan mencapai 1,2 milyar (Nugroho, 2000). Menurut Kinsella \& Taeuber (2000) Indonesia diperkirakan akan menjadi Negara ke5 yang paling banyak lansianya di tahun 2025, sedangkan menurut Perserikatan Bangsa-Bangsa (PBB) memperkirakan bahwa di Indonesia tahun 2050 jumlah warga Lansia akan mencapai \pm 60 juta jiwa menduduki peringkat ke-4 dari seluruh dunia (Notoatmodjo, 2007).

Hipertensi merupakan salah satu penyakit degeneratif yang sering dijumpai pada kelompok lansia (Abdullah, 2005), pada penelitian di Rotterdam, Belanda ditemukan prevalensi hipertensi $(160 / 95 \mathrm{mmHg})$ meningkat sesuai dengan umur, lebih tinggi pada perempuan (39\%) dari pada laki-laki (31\%), sedangkan di Asia berdasarkan The Joint National Committee on Prevention, Detection, Evaluation, and Treatment of High Bloodpressure (JNC VI), ditemukan prevalensi hipertensi sebesar $60,4 \%$ (laki-laki 59,1\% dan perempuan $61,9 \%$ ).

Menurut penelitian Syukraini (2009), di Nagari Bungo Tanjung Sumatera Barat diperoleh bahwa faktor-faktor yang berhubungan dengan penyakit hipertensi pada lansia yaitu: faktor umur, jenis kelamin, konsumsi rokok, konsumsi garam berlebih, konsumsi lemak, genetik, dan riwayat penyakit komplikasi. Pada penelitian 
lain di kabupaten Karanganyar menemukan bahwa faktor-faktor yang berhubungan dengan hipertensi adalah faktor umur, genetik, konsumsi asin, konsumsi lemak jenuh, penggunaan jelantah, kurang olahraga, olahraga tidak ideal, obesitas, dan konsumsi kontrasepsi tablet (Sugiarto, 2007).

Penelitian ini bertujuan untuk mengetahui faktor-faktor yang berhubungan dengan kejadian hipertensi pada lansia.

\section{METODE}

Penelitian ini menggunakan desain deskriptif analitik dengan pendekatan Cross Sectional, yang dilaksanakan di wilayah kerja Puskesmas III Denpasar Utara dari bulan April - Mei 2012. Populasi pada penelitian ini adalah semua lansia hipertensi yang berobat ke Puskesmas III Denpasar Utara dengan jumlah kunjungan lansia penderita hipertensi pada bulan Juli - Desember 2011 sebanyak 315 kasus, dengan tehnik Consecutiv Sampling yaitu cara pengambilan sampel yang dilakukan dengan memilih sampel yang memenuhi kriteria penelitian sampai kurun waktu tertentu sehingga jumlah sampel terpenuhi (Sugiyono, 2001).

Pengumpulan data hipertensi dilakukan dengan pemeriksaan menggunakan alat spignometer raksa dan stetoskop, data karakteristik (umur, jenis kelamin), genetik, aktivitas, kebiasaan minum kopi, konsumsi alcohol, merokok, konsumsi kontrasepsi tablet, konsumsi garam berlebih, dan tingkat stress dilakukan dengan cara wawancara menggunakan pedoman kuesioner. Sedangkan data status gizi (obesitas) dilakukan dengan pemeriksaan BB dan TB menggunakan timbangan injak digital (seca) dan mistar plastik.

Data yang telah terkumpul kemudian diolah menggunakan program spss untuk dilakukan analisis bivariat untuk mengetahui hubungan antara variabel dependen dan variabel independen menggunakan uji Chi Square dengan derajat kemaknaan 0,05 . Bila nilai $p$-value $<\alpha(0,05)$ berarti hasil perhitungan statistik bermakna (signifikan), dan apabila nilai $p$-value $>\alpha(0,05)$ berarti hasil perhitungan statistik tidak bermakna (tidak signifikan).

Jurnal Kesehatan Medika Udayana Vol.04 No.01 April 2018 Jage 13 


\section{HASIL}

Berdasarkan analisis Bivariat diperoleh bahwa faktor-faktor yang berhubungan dengan kejadian hipertensi pada lansia adalah faktor umur (OR:10,833; 95\%CI: 1,961-59,834), faktor jenis kelamin (OR:7,467; 95\%CI:1,400-39,837), faktor genetik OR:10,083; 95\%CI:1,658-61,330), faktor aktivitas (OR:0,095; 95\%CI:0,0170,529), dan kebiasaan minum kopi (OR:15,556; 95\%CI:2,586-93,571).

Analisis bivariate yang dijabarkan pada table 1 menunjukkan bahwa, dari 14 lansia yang umur 60-70 tahun ada $10(71,4 \%)$ lansia yang menderita pre hipertensi dan $4(28,6 \%)$ lansia yang menderita hipertensi HST sedangkan dari 16 lansia yang umur 71-80 tahun ada $3(18,8 \%)$ lansia yang menderita pre hipertensi dan $13(81,3 \%)$ lansia yang menderita hipertensi HST serta tidak ada lansia yang umur > 80 tahun yang menderita pre hipertensi dan HST. Selanjutnya pada variable jenis kelamin diketahui bahwa dari 11 lansia yang berjenis kelamin laki-laki ada 8 (72,7\%) lansia yang menderita pre hipertensi dan 3(27,3\%) lansia yang menderita hipertensi HST sedangkan dari 19 lansia yang berjenis kelamin perempuan ada $5(26,3 \%)$ lansia yang menderita pre hipertensi dan 14(73,7\%) lansia yang menderita hipertensi HST. Pada variable genetik menunjukkan bahwa dari 17 lansia yang mempunyai faktor genetik ada $11(64,7 \%)$ lansia yang menderita pre hipertensi dan $6(35,3 \%)$ lansia yang menderita hipertensi HST sedangkan dari 13 lansia yang tidak mempunyai faktor genetik ada $2(15,4 \%)$ lansia yang menderita pre hipertensi dan 11(84,6\%) lansia yang menderita hipertensi HST. Untuk variable aktivitas diperoleh bahwa dari 18 lansia yang kurang aktivitas ada $4(22,2 \%)$ lansia yang menderita pre hipertensi dan 14(77,8\%) lansia yang menderita hipertensi HST sedangkan dari 12 lansia yang tidak kurang aktivitas ada 9 (75\%) lansia yang menderita pre hipertensi dan3 (25\%) lansiayang menderita hipertensi HST. Variable terakhir yaitu kebiasaan minum kopi memperoleh bahwa dari 13 lansia yang mempunyai kebiasaan minum kopi ada $10(76,9 \%)$ lansia yang menderita pre hipertensi dan $3(23,1 \%)$ lansia yang menderita hipertensi HST sedangkan dari 17 lansia yang tidak mempunyai kebiasaan minum kopi ada $3(17,6 \%)$ lansia yang menderita pre hipertensi dan $14(82,4 \%)$ lansia yang menderita hipertensi HST

Jurnal Kesehatan Medika Udayana Vol.04 No.01 April 2018 Page 14 
Tabel 1. Analisis Bivariat (Crosstabs) Determinan Hipertensi Pada Lansia.

\begin{tabular}{|c|c|c|c|c|c|c|c|}
\hline \multirow{2}{*}{ No } & \multirow{2}{*}{ Variabel } & \multicolumn{2}{|c|}{ Pre-hipertensi } & \multicolumn{2}{|c|}{ HST } & \multirow[t]{2}{*}{ OR (95\%CI) } & \multirow[t]{2}{*}{ p-value } \\
\hline & & $\mathbf{n}$ & $\%$ & $\mathbf{n}$ & $\%$ & & \\
\hline 1 & $\begin{array}{c}\text { Umur: } \\
60-70 \\
71-80 \\
>80\end{array}$ & $\begin{array}{c}10 \\
3 \\
0\end{array}$ & $\begin{array}{c}71,4 \\
18,8 \\
0\end{array}$ & $\begin{array}{c}4 \\
13 \\
0\end{array}$ & $\begin{array}{c}28,6 \\
81,3 \\
0\end{array}$ & $\begin{array}{l}10,833 \\
(1,961- \\
59,834)\end{array}$ & 0,011 \\
\hline 2 & $\begin{array}{c}\text { Jenis kelamin: } \\
\text { Laki-laki } \\
\text { Perempuan }\end{array}$ & $\begin{array}{l}8 \\
5\end{array}$ & $\begin{array}{l}72,7 \\
26,3\end{array}$ & $\begin{array}{c}3 \\
14\end{array}$ & $\begin{array}{l}27,3 \\
73,7\end{array}$ & $\begin{array}{c}7,467 \\
(1,400- \\
39,836)\end{array}$ & 0,023 \\
\hline 3 & $\begin{array}{c}\text { Genetik: } \\
\text { Ya } \\
\text { Tidak }\end{array}$ & $\begin{array}{c}11 \\
2\end{array}$ & $\begin{array}{l}64,7 \\
15,4\end{array}$ & $\begin{array}{c}6 \\
11\end{array}$ & $\begin{array}{l}35,3 \\
84,6\end{array}$ & $\begin{array}{l}10,083 \\
(1,658- \\
61,330)\end{array}$ & 0,020 \\
\hline 4 & $\begin{array}{c}\text { Kurang aktivitas: } \\
\text { Ya } \\
\text { Tidak }\end{array}$ & $\begin{array}{l}4 \\
9\end{array}$ & $\begin{array}{c}22,2 \\
75\end{array}$ & $\begin{array}{c}14 \\
3\end{array}$ & $\begin{array}{c}77,8 \\
25\end{array}$ & $\begin{array}{c}0,095 \\
(0,017-0,529)\end{array}$ & 0,013 \\
\hline 5 & $\begin{array}{c}\text { Minum kopi: } \\
\text { Ya } \\
\text { Tidak }\end{array}$ & $\begin{array}{c}10 \\
3\end{array}$ & $\begin{array}{l}76,9 \\
17,6\end{array}$ & $\begin{array}{c}3 \\
14\end{array}$ & $\begin{array}{l}23,1 \\
82,4\end{array}$ & $\begin{array}{l}15,556 \\
(2,586- \\
93,571)\end{array}$ & 0,004 \\
\hline 6 & $\begin{array}{c}\text { Obesitas: } \\
\text { Ya } \\
\text { Tidak }\end{array}$ & $\begin{array}{l}7 \\
6\end{array}$ & $\begin{array}{c}50 \\
37,5\end{array}$ & $\begin{array}{c}7 \\
10\end{array}$ & $\begin{array}{c}50 \\
62,5\end{array}$ & $\begin{array}{c}0,600 \\
(0,140-2,575)\end{array}$ & 0,749 \\
\hline 7 & $\begin{array}{c}\text { Konsumsi } \\
\text { alcohol: } \\
\text { Ya } \\
\text { Tidak }\end{array}$ & $\begin{array}{c}2 \\
11\end{array}$ & $\begin{array}{l}33,3 \\
45,8\end{array}$ & $\begin{array}{c}4 \\
13\end{array}$ & $\begin{array}{l}66,7 \\
54,2\end{array}$ & $\begin{array}{c}0,591 \\
(0,090-3,864)\end{array}$ & 0,672 \\
\hline 8 & $\begin{array}{c}\text { Merokok: } \\
\text { Ya } \\
\text { Tidak }\end{array}$ & $\begin{array}{c}3 \\
10\end{array}$ & $\begin{array}{l}27,3 \\
52,6\end{array}$ & $\begin{array}{l}8 \\
9\end{array}$ & $\begin{array}{l}72,7 \\
47,4\end{array}$ & $\begin{array}{c}0,338 \\
(0,068-1,678)\end{array}$ & 0,259 \\
\hline 9 & $\begin{array}{c}\text { Kontrasepsi } \\
\text { tablet: } \\
\text { Ya } \\
\text { Tidak }\end{array}$ & $\begin{array}{l}3 \\
2\end{array}$ & $\begin{array}{l}42,9 \\
16,7\end{array}$ & $\begin{array}{c}4 \\
10\end{array}$ & $\begin{array}{l}57,1 \\
83,3\end{array}$ & $\begin{array}{c}3,750 \\
(0,445- \\
31,621)\end{array}$ & 0,305 \\
\hline 10 & $\begin{array}{c}\text { Konsumsi } \\
\text { garam: } \\
\text { Ya } \\
\text { Tidak }\end{array}$ & $\begin{array}{l}8 \\
5\end{array}$ & $\begin{array}{l}57,1 \\
31,3\end{array}$ & $\begin{array}{c}6 \\
11\end{array}$ & $\begin{array}{l}42,9 \\
68,8\end{array}$ & $\begin{array}{c}2,933 \\
(0,657- \\
13,093)\end{array}$ & 0,290 \\
\hline 11 & $\begin{array}{c}\text { Tingkat stress: } \\
\text { Tidak stress } \\
\text { Ringan } \\
\text { Sedang } \\
\text { berat }\end{array}$ & $\begin{array}{l}6 \\
7 \\
0 \\
0\end{array}$ & $\begin{array}{c}50,0 \\
38,9 \\
0 \\
0\end{array}$ & $\begin{array}{c}6 \\
11 \\
0 \\
0\end{array}$ & $\begin{array}{c}50 \\
61,1 \\
0 \\
0\end{array}$ & $\begin{array}{c}1,571 \\
(0,359-6,875)\end{array}$ & 0,821 \\
\hline
\end{tabular}




\section{PEMBAHASAN}

Hasil penelitian di wilayah kerja puskesmas III Denpasar timur memperoleh hasil bahwa, faktor umur berhubungan dengan kejadian hipertensi pada lansia (OR:10,833; 95\%CI: 1,961-59,834). Hasil ini sejalan dengan penelitian di kota Tainan, Taiwan menunjukkan hasil, prevalensi hipertensi pada lansia diatas 60 tahun sebesar 60,4\% (laki-laki 59,1\% dan perempuan 61,9\%) (Kuswardhani, 2007). Sedangkan penelitian di Rotterdam, Belanda mendapatkan, dari 7983 penduduk berusia diatas 55 tahun, prevalensi hipertensi terus meningkat sesuai dengan umur, lebih tinggi pada perempuan (39\%) dan pada laki-laki (31\%). Peningkatan umur akan menyebabkan beberapa perubahan fisiologis pada usia lanjut terjadi peningkatan resistensi perifer dan aktivitas simpatik. Pengaturan tekanan darah yaitu reflek baroreseptor pada lansia sensitivitasnya sudah berkurang sedangkan peran ginjal juga sudah berkurang dimana aliran darah ginjal dan laju filtrasi glomerulus menurun (Anggraini, 2009).

Penelitian ini juga mendapatkan hasil bahwa, jenis kelamin berhubungan dengan kejadian hipertensi pada lansia (OR:7,467; 95\%CI:1,400-39,837). Hasil ini sejalan dengan penelitian Syukraini (2009), di Nagari Bungo Tanjung, Sumatera Barat menunjukkan bahwa resiko untuk menderita hipertensi bagi wanita 5 kali lebih besar dibandingkan pria. Wanita yang belum mengalami menopause dilindungi oleh hormon estrogen yang berperan dalam meningkatkan kadar High Density Lipoprotein (HDL). Kadar kolesterol HDL yang tinggi merupakan faktor pelindung dalam mencegah terjadinya proses aterosklerosis. Efek perlindungan estrogen dianggap sebagai penjelasan adanya imunitas wanita pada usia kehilangan sedikit demi sedikit hormon estrogen yang selama ini melindungi pembuluh darah dari kerusakan. Proses ini terus berlanjut dimana hormon estrogen tersebut berubah kuantitasnya sesuai dengan umur wanita secara alami, yang umumnya mulai terjadi pada wanita umur 45-55 tahun. Dari hasil penelitian didapatkan lebih dari setengah penderita hipertensi berjenis kelamin wanita sekitar 56,5\%. (Anggraini, 2009). 
Selanjutnya, penelitian ini juga memperoleh hasil bahwa faktor genetik berhubungan dengan kejadian hipertensi pada lansia (OR:10,083; 95\%CI:1,65861,330). Hasil ini sejalan dengan penelitian Marliani (2007), yang mendapatkan bahwa seseorang akan memiliki kemungkinan lebih besar untuk mendapatkan hipertensi jika orang tuanya adalah penderita hipertensi. Menurut Anggraini (2009) bahwa adanya faktor genetik pada keluarga tertentu akan menyebabkan keluarga itu mempunyai resiko menderita hipertensi. Hal ini berhubungan dengan peningkatan kadar sodium intraseluler dan rendahnya rasio antara potasium terhadap sodium individu dengan orang tua dengan hipertensi mempunyai resiko dua kali lebih besar untuk menderita hipertensi dari pada orang yang tidak mempunyai keluarga dengan riwayat hipertensi.

Pada variable aktivitas, peneliti mendapatkan hasil bahwa, faktor kurangnya aktivitas berhubungan dengan kejadian hipertensi pada lansia (OR:0,095; 95\%CI:0,017-0,529). Hal ini sejalan dengan penelitian yang dilakukan oleh Hemelahti, et al (1998). Mereka menyatakan bahwa kurang aktivitas/olahraga akan meningkatkan resiko terkena hipertensi sebesar 2,33 kali dibanding dengan yang biasa beraktivitas/olahraga. Hasil ini juga didukung oleh Rohaendi (2008), bahwa kurang aktivitas berpengaruh terhadap kerja detak jantung lebih cepat dan otot jantung mereka harus bekerja lebih keras pada setiap kontraksi, semakin keras dan sering jantung harus memompa semakin besar pula kekuatan yang mendesak arteri. Berdasarkan hasil survey kesehatan rumah tangga survei kesehatan rumah tangga (2001) didapatkan hasil bahwa yang melakukan olah raga 3 kali atau lebih per minggu hanya 14,3\% (Depkes RI, 2000).

Hasil terakhir yang diperoleh pada penelitian ini adalah adanya hubungan antara kebiasaan minum kopi dengan kejadian hipertensi pada lansia (OR:15,556; 95\%CI:2,586-93,571). Hal ini sejalan dengan penelitian yang dilakukan di Lampung, yang mendapatkan hasil bahwa seseorang yang mengonsumsi kopi lebih dari satu kali per hari memiliki resiko terjadinya hipertensi sebesar 4,52 kali daripada seseorang yang hanya minum kopi sekali sehari atau jarang (Ernita, 2011). Sesuai dengan teori bahwa didapatkan dalam satu cangkir kopi mengandung 75-200 mg kafein yang dapat 
menstimulasi jantung untuk bekerja lebih cepat sehingga berpotensi untuk meningkatkan tekanan darah 5-10 mmHg (Anggraini, 2009). Namun menurut Uiterwaal, et al (2007) menyatakan bahwa minum kopi tidak selalu berefek buruk yang sama pada semua orang, karena hasil yang berbeda diperoleh pada penelitian di Amerika Serikat yang menemukan bahwa, mengonsumsi banyak kopi tidak meningkatkan resiko hipertensi. Sesuai dengan laporan The American Journal of Clinical Nutrition menunjukkan bahwa dari 170.000 orang yang mempunyai kebiasaan mengonsumsi kopi lebih dari tiga cangkir per hari tidak berhubungan dengan peningkatan resiko hipertensi dibandingkan dengan kurang dari satu cangkir per hari.

\section{SIMPULAN DAN SARAN}

Terdapat hubungan yang bermakna antara umur, jenis kelamin, genetik, aktifitas dan kebiasaan minum kopi dengan kejadian hipertensi pada lansia. Tidak terdapat hubungan yang bermakna antara obesitas, minum alkohol, konsumsi garam berlebih, konsumsi kontrasepsi tablet, merokok, dan tingkat stress dengan kejadian hipertensi pada lansia. Diharapkan pihak terkait rutin dalam melaksanakan deteksi dini penyakit tidak menular (PTM) dan lebih gencar dalam mempromosikan program-program kesehatan khususnya pada kelompok lansia.

\section{UCAPAN TERIMAKASIH}

Terima kasih peneliti ucapkan kepada Akper Kesdam IX/Udayana yang telah memberikan kesempatan dan dukungan pada peneliti untuk menyelesaikan penelitian ini.

\section{DAFTAR PUSTAKA}

Abdullah, Masqon (2005). Faktor yang berhubungan dengan kejadian hipertensi pada kelompok usia lanjut dikecamatan pengandon kabupaten Kendal, http://www.fkm.undip.ac.id/data/index.php?action=4\&idx=2701, diakses tanggal 25 November 2011. 
Anggraini. (2009). Faktor-faktor yang berhubungan dengan hipertensi pada kelompok lansia. (http://one.indoskripsi.com/judul-skripsi-tugas-makalah/kedokteran/hipertensi kelompok lansia) diakses tanggal 25 November 2011

Depkes RI. (2000). Survei Kesehatan Rumah Tangga (SKRT). Jakarta

Ernita. (2011). "Hubungan Kebiasaan Minum Kopi Terhadap Kejadian Hipertensi Pada LakiLaki di Kota Lhokseumawe Provinsi Nanggro Aceh Darussalam”. Tesis. Yogyakarta. Minat Utama Gizi dan Kesehatan Program Ilmu Kesehatan Masyarakat. UGM

Hemelathi M, Kujala UM, Kaprio J, et al. (1998). Hypertension in master endurance athletes. J. Hypertens 1998;16 (11): 1573-7 (ISSN : 0263 - 6352)

Kuswardhani,Tuty (2007). Penatalaksanaan Hipertensi pada Lansia. (http://ejournal.unud.ac.id/abstrak/penatalaksanaan\%20hipertensi\%20pada\%20usia\%2 Olanjut.pdf.), diakses 25 November 2011

Marliani. (2007). 100 Question \& Answers Hipertensi, PT Elex Media Komputindo. Jakarta : Gramedia.

Notoatmodjo, Soekidjo. (2007). Metodologi Penelitian Kesehatan. Jakarta : Rineka Cipta

Nugroho. (2000). Keperawatan Komunitas . Jakarta : Salemba Medika

Rohaendi. (2008). Hipertensi. http: /// rohaendi. Blogspot. Com/2008/06/hipertensi.html. diakses : 11 November 2011, pukul 20.00 Wita

Sugiharto, Aris. (2007). Faktor-Faktor Resiko Hipertensi Grade II. http: I/I Sugiharto. Blogspot. Com/2007/06/hipertensi.html.diakses : 11 November 2011, pukul 20.00 Wita

Syukraini. (2009). Analisis Faktor Resiko Hipertensi pada Masyarakat Nagari Bungo Tanjung Sumatera Barat. http: /// Syukraini. Blogspot. Com/2009/06/hipertensi.html. diakses : 11 November 2011, pukul 20.00 Wita

Sugiyono. (2004). Statistika Untuk Penelitian. Bandung : Alfabeta.

Uiterwaal, C. S. P. M., Verschuren, W. M. N., Bueno-de-Mesquita, H. B., Ocke, M., Geleijnse, J. M., Boshuizen, H. C et al. (2007). Coffe intake and incidence of hypertension. American Journal Clinical Nutrition, 85(3), 718-23. Diakses dari http://www.jclinnutr.com 